\title{
THE POWER OF INFORMATION: EVIDENCE FROM A NEWSPAPER CAMPAIGN TO REDUCE CAPTURE*
}

\author{
Ritva ReInIKKA ${ }^{\dagger}$ AND JAKOB SvenSSON ${ }^{\ddagger}$ \\ DeCEMBER, 2003
}

This paper exploits an unusual policy experiment to evaluate the effects of increased public access to information as a tool to reduce capture and corruption of public funds. In the late 1990s, the Ugandan government initiated a newspaper campaign to boost schools' and parents' ability to monitor local officials' handling of a large school-grant program. The results were striking: capture was reduced from 80 percent in 1995 to less than 20 percent in 2001. We use distance to the nearest newspaper outlet as an instrument for exposure to the campaign. Proximity to a newspaper outlet is positively correlated with the head teachers' knowledge about rules governing the grant program and the timing of releases of funds from the center, but uncorrelated with test scores of general ability. A strong (reduced-form) relationship exists between proximity to a newspaper outlet and reduction in capture of school funds since the newspaper campaign started. This pattern contrasts sharply with the outcomes in the five-year period prior to the campaign. Instrumenting for head teachers' knowledge about the grant program, we find that public access to information is a powerful deterrent to capture at the local level.

${ }^{*}$ Views expressed here do not represent official opinions of the World Bank. We wish to thank IDC Limited (Kampala), Andreas Madestam, and Abel Ojoo for their excellent work at the survey stage, and the World Bank Research Committee and the Swedish International Development Agency, Department for Research Cooperation, SAREC, for generous funding. We are also grateful for comments and suggestions by Michael Kremer, David Strömberg, Per Pettersson-Lidbom, and conference participants from the European Development Research Network and the European Science Foundation.

${ }^{\dagger}$ Development Research Group, The World Bank. Email: rreinikka@worldbank.org.

${ }^{\ddagger}$ Institute for International Economic Studies, Stockholm University, Development Research Group, The World Bank, and CEPR. Email: jakob.svensson@iies.su.se. 


\section{INTRODUCTION}

A common thread in most anticorruption programs is the reliance on legal and financial institutions - judiciary, police, financial auditors - to enforce and enhance accountability in the public sector. However, in many poor countries, these institutions are weak and among the most corrupt. Not surprisingly, there are few recent examples of successful efforts to combat corruption and capture in public programs. ${ }^{1}$

A complementary approach takes the users of public services as a starting point. Rather than attempting to increase service providers' accountability to policymakers alone, the idea is to also engage citizens at the bottom of the public service delivery chain by providing them with easy access to information on the workings of public programs intended for their benefit. In this way, citizens will be empowered to demand certain standards and monitor and challenge abuses by officials they interact with in their daily lives. Improving public access to information is a crucial part in this bottomup strategy. However, although buzzwords like "information," "knowledge," and "empowerment" pepper the current policy debate on development, there is little quantitative evidence on the impact of policy measures aimed at achieving them (Banerjee and He 2003). This paper attempts to reduce this gap.

We examine an unusual policy experiment - an information campaign in Uganda aimed at reducing the capture of public funds by providing schools (parents) with information to monitor local officials' handling of a large school-grant program. In the mid-1990s, a public expenditure tracking survey (PETS) revealed that for every dollar spent by the central government,

\footnotetext{
${ }^{1}$ The legal approach runs into problems as legal systems to control public sector mismanagement rely on the existence of a trustworthy (benevolent) legal machinery (judges, court personnel, police) able to investigate and enforce existing rules. Many countries, in particular those characterized by systemic corruption, have no such legal systems. The financial management approach suffers from the same dependency on a credible institutional framework. An efficient financial system relies on a functioning enforcement mechanism and the ability to delegate reviews to trustworthy auditors. While well-functioning legal and financial systems minimize obvious cases of mismanagement, rules and accounting systems only partially constrain the discretionary powers of public sector managers and employees. The complexity of the tasks performed by a typical public sector unit and its informational advantage relative to customers effectively hinder the design of legal and accounting measures to address all types of inefficiencies. Thus, less obvious measures of mismanagement (such as shirking, budget prioritization that favors staff at the expense of customers, certain procurement procedures, political considerations) typically go undiscovered. Finally, auditing reports and legal procedures are often difficult for the layman to interpret, and therefore go unnoticed unless the agency who commissioned the audit acts on them.
} 
the schools received only 20 cents on average (Reinikka and Svensson 2004). As evidence of the degree of local capture became known, the central government enacted a series of policy changes. Specifically, it began to publish data on monthly transfers of capitation grants to local governments (districts) in newspapers. We use a repeat PETS to study the effects of increased public access to information as a tool to reduce capture and corruption.

The raw data suggest a large improvement. In 2001, schools received 80 percent on average of their annual entitlements.

We first examine outcomes across schools with and without access to newspapers. Intuitively, schools with access to newspapers have been more extensively exposed to the information campaign. The difference-in-differences estimates show that while the degree of capture was similar in the groups with and without access to newspapers in mid-1990s, the more extensively treated schools suffered significantly less from local capture in 2001. Data from a simple knowledge test administered to head teachers provide additional support for the hypothesis that improved access to information has played an important role in reducing local capture. Specifically, we find that head teachers with access to newspapers, on average, are better acquainted with the rules governing the grant program and the timing of releases of funds from the center. However, in a test of local and general knowledge, head teachers with access to newspapers score as well as those lacking access, suggesting that it is information on the grant program (disseminated through newspapers) rather than some unobserved characteristic (e.g., ability) correlated with newspaper access, that accounts for the observed effects.

Access to a newspaper, however, only identifies a causal effect of improved access to information under certain conditions. Specifically, newspaper access is partly endogenous. Moreover, a head teacher may be well-informed about the grant program even if he/she does not have newspapers, when parents in the community where the school is located have access to them. To overcome these problems, we instrument for exposure to the information campaign by using distance to the nearest newspaper outlet.

Distance to the nearest newspaper outlet is significantly correlated with both schools' access to a newspaper and head teachers' test scores on knowledge of the workings of the grant program, but uncorrelated with other types of knowledge or test scores that measure general ability. A strong (reducedform) relationship exists between proximity to a newspaper outlet and reduction in capture since the newspaper campaign started, which represents a significant change in pattern from the five-year period preceding the campaign. Instrumenting for head teachers' knowledge about the grant program, we find that public access to information is a powerful deterrent to capture of funds at the local level. 
This paper relates to two different areas of research. There is a small but growing literature on the role of mass media in shaping public policy. Strömberg $(2003,2004)$ considers how the press influences redistributive programs in a model of electoral policies, where the role of the media is to raise voter awareness and thereby increase the sensitivity of turnout to favors granted. Besley and Burgess (2002) focus on the media's role in increasing political accountability, also in a model of electoral policies. Our focus is on how the execution of already determined policies (a capitation grant program for primary schools) is affected by having more informed citizens. Empirically, we use micro data from schools rather than disaggregated national accounts data.

Our work also links to the empirical literature on corruption. With few exceptions, this literature has three common features. It is based on crosscountry analyses; it exploits data on corruption derived from perception indices, typically constructed from foreign experts' assessments of overall corruption in a country; and it explains corruption as a function of the country's politico-institutional environment. ${ }^{2}$ The research on corruption and the media exemplifies this approach (see Brunetti and Weder [2003] and Ahrend [2002])..$^{3}$ While the literature has provided important insights, it also has its drawbacks, including concerns of perception biases and causation. ${ }^{4}$ Our work complements the cross-country approach. We provide quantitative, microlevel evidence from a policy experiment on the effects of increased public access to information as a tool to combat capture and corruption.

The rest of the paper is organized as follows. Section II describes the

\footnotetext{
${ }^{2}$ See Svensson [2003] for a discussion. For the effects of corruption on investment and growth, see Mauro [1995]. On the determinants of corruption, see Ades and Di Tella [1997, 1999], Persson, Tabellini, and Trebbi [2001], Svensson [2000], and Treisman [2000]. A common theme in this literature is the use of subjective measures of corruption in a cross-country setting. Di Tella and Schargrodsky [2003], Reinikka and Svensson [2004], and Svensson [2003] are exceptions. They use quantitative micro-level data on corruption. Hellman et al. [2000a,b] also use firm-level data. The data is numerical but ordinal (based on multi-category responses to questions on corruption). In line with the cross-country literature, they explain corruption as a function of the politico-institutional environment.

${ }^{3}$ See also Djankov et al. [2003], who gather new data on media ownership and show that state ownership is correlated with both less media freedom and more corruption.

${ }^{4}$ Brunetti and Weder [2003] and Ahrend [2002] use a corruption perception index compiled by the International Country Risk Guide (ICRG). Perception biases may occur if, for example, improved protection of journalists reporting on corruption is perceived (by ICRG) as lowering the cost of doing business due to corruption. In this case, there would be a direct link between freedom of media and the risk rating score published by ICRG. Establishing a correlation between freedom of the media and corruption does not provide strong evidence of a causal link since both measures are highly correlated with several other institutional characteristics that may explain the level of corruption in a country.
} 
pre-campaign situation and discusses findings from the earlier study on local capture. Section III lays out the key components of the public information campaign. Section IV describes the survey data used in the empirical analysis and the method used to quantify capture. Section V presents the empirical evidence, and section VII concludes.

\section{The PRE-CAMPAIGN SITUATION}

In an ideal setting, the public accounting system would provide timely information about actual spending on various budget items and programs, and the reports would accurately reflect what the intended users receive. This is not often the case in low-income countries. Typically, the accounting system functions poorly, institutions enhancing local accountability are weak, and there are few (if any) incentives to maintain adequate records at different levels of government. Consequently, little is known about the efficiency of transforming budget allocations into services within most sectors.

These observations formed the basis for designing a new survey tool-a public expenditure tracking survey (PETS) - to gauge the extent to which public resources actually filtered down to the intended facilities. ${ }^{5}$

A survey of 250 government primary schools, 18 local governments (districts), and 3 central government ministries was implemented in 1996, covering the period 1991-95. At the time of the survey, about 8,500 government primary schools were supposed to receive a large proportion of their funding from the central government via local government administrations.

The objective of the survey was twofold. First, it measured the difference between intended resources (from the central government) and resources actually received (by the school). Second, it collected quantitative data on service delivery on the front line (i.e., the schools).

Focusing on the capitation grant program had two advantages. First, like most public programs at that time, the capitation grant was a national program in which local (district) offices were used as distribution channels. This gave local officials and politicians the opportunity to capture the funds. Second, unlike other government programs, the capitation grant was a rare liquid money infusion into local administrative and political systems, which made is easier to capture the funds. Other public programs were primarily in-kind (for instance, health clinics were provided with drug kits), and hence harder to capture.

\footnotetext{
${ }^{5}$ For a conceptual discussion on the PETS and the related Quantitative Service Delivery Survey (QSDS), as well as references to ongoing survey work, see Dehn, Reinikka, and Svensson [2003] and Reinikka and Svensson [2003].
} 
Detailed records were available at both the central level and at schools. At the district level, the survey team was able to obtain book-keeping information on receipts from the central government at the offices of the chief administrative officer and the regional audit representative, but not records of disbursements to individual schools.

Several pieces of information suggest that the capitation grant data at the school level adequately reflected what the schools received. First, the data were collected directly from the school records. These records were kept for the schools' own needs and were often of relatively good quality. ${ }^{6}$ Because the school records were not submitted to any district or central authorities and did not constitute a basis for current or future funding, there were no obvious incentives to misrecord the data. At the same time, parents contributing the majority of school income demanded financial information and accountability from the school (or PTA), so school records were usually relatively well-kept. Most of the public resources received by schools were in-kind (textbooks, stationery, chalk, etc.) and information on all these inputs was collected and subsequently valued (using market prices). The concern that head teachers might have underreported the school income in order to extract resources for themselves was allayed after interviews during the survey work, which did not support this claim. This is not surprising since the PTA was typically the principal decision-maker (and responsible for raising most of the funds) at the school.

Monthly reports from the Uganda Computer Centre, based on issued cheques, reveal that the capitation grants were fully released by the central government on a monthly basis. ${ }^{7}$ In the Ugandan treasury system, central ministries or individuals were unlikely to be able to capture central releases since they were subject to relatively elaborate pre-audit procedures. In addition, since the capitation grant program was given a priority program status as part of the World Bank's structural adjustment programs, the releases from the center were also externally audited (by World Bank staff). Most im-

\footnotetext{
${ }^{6}$ As discussed in Reinikka and Svensson [2004], 5 of the 250 schools surveyed lacked any records and thus had to be dropped from the sample. Another 56 schools had missing records for at least one year in the survey period. As a group, these schools do not differ significantly in observable school characteristics, such as income or school quality (measured by the share of unqualified teachers), although there is some evidence that smaller schools are less likely to have records for the whole survey period.

${ }^{7}$ In most cases, 100 percent and always well over 90 percent of the funds were released. The procedure at the time was that the Ministry of Local Government (MOLG) would receive funds for the capitation grants from the Ministry of Finance into their account, and, in turn, the MOLG would have a Uganda Commercial Bank (UCB) cheque prepared for each district. The districts would simply collect their cheques from the MOLG and deposit them into their account with a branch of UCB in their district.
} 
portantly, records at the district level confirmed that the disbursed amounts were actually received by the districts.

The results of the pre-campaign survey are shown in Table 1 . In the mid-1990s, only 24 percent of the total capitation grant from the central government reached the schools. ${ }^{8}$ Thus, for every dollar spent on nonwage education items by the central government, roughly 80 cents were captured by local government officials (and politicians). In fact, a majority of schools received nothing. As shown in Reinikka and Svensson [2004], poor students suffered disproportionately due to local capture, because schools catering to them received less than the others.

Where did the money end up? There was no evidence of increased spending in other sectors (Jeppsson [2001], McPake et al. [1999]). There is indirect evidence that part of the leakage was theft, as indicated by numerous newspaper articles about indictments of district education officers after the survey findings went public. However, most evidence suggests that funds were largely used for patronage politics and funding of different political activities. For example, there are many anecdotes about funds being used to increase allowances for councillors and bureaucrats, and when funds were actually received by the local offices, well-connected citizens and local politicians met with district officials to decide how they should be used.

These anecdotes are consistent with case study evidence of (local) political financing and corruption in Uganda, as reported in Thomas [1998, 1999]. Thomas argues that the power in local governments is concentrated in a small pool of elites interconnected by common schooling, marriage, friendships, shared ethnicities or religion. Sustaining this power balance is costly and public funds are fueling a system of patronage politics, where patrons give clients material rewards for their political loyalty and services (see also Bayart [1993]).The patronage system takes different forms, including government actors diverting public resources for their own campaigns and those of friends and family, and financing of local and private causes, including distribution of private goods such as salt, sugar, and beer to neutralize voter dissatisfaction. Political parties, in the case of Uganda "the Movement," must also supply patronage goods to their workers and members. ${ }^{9}$ In a rural setting, an important way of maintaining an effective political organization is through personal presence, which means a well-staffed institutional hier-

\footnotetext{
${ }^{8}$ The value for 1995 is the 1995 value if data is available for that year, otherwise it is the value for the previous year.

${ }^{9}$ The National Resistance Movement is not a formal official party, although it operates like one and its institutional structure is similar to other dominant party structures in other parts of Sub-Saharan Africa, with a National Executive Committee, a Secretariat, and District, Division, Sub-County, Town, Parish, and Village Movement Committees.
} 
archy all the way down to the village level. This model requires substantial resources, and diversion of public resources is often the only source of funding available. The discretionary use of funds to support the local political apparatus was also facilitated by the fact that most schools (teachers and parents) did not know that they were entitled to capitation grants.

\section{INFORMATION CAMPAIGN}

As the extent of local government capture became known (thanks to the first PETS survey), the central government reacted swiftly to improve the situation. Interestingly, rather than initiating (another) reform project to improve of the financial management system; i.e., the standard approach, it decided to take the route of citizen empowerment. Following a cabinet meeting to discuss the capture problem, the central government, led by the Ministries of Local Government and Finance, began to publish data on monthly transfers of capitation grants to districts in the national newspapers and their local language editions. This practice was extended to transfers in other sectors soon after. ${ }^{10}$

Following the introduction of universal primary education in 1997, the Ministry of Education, supported by donor agencies, proposed extending the information campaign to all school communities (Stasavage [2003]). This policy required primary schools (and district administration headquarters) to post notices on actual receipts of funds for all to see. In other words, information on entitlements (transfers by central government) was made available through the newspaper campaign, while the posted notices informed parents about what had actually been received at the school level.

The central government also initiated new monitoring and supervision activities, following the first PETS survey. These measures promoted accountability in two ways. First, by giving schools access to information on their entitlements and the workings of the grant program, head teachers and parents could themselves monitor the local administration and voice complaints if funds did not reach the schools. Similarly, at the school level parents could better monitor the head teacher and voice complaints in case of any misconduct. Second, the crackdown on officers found to be misusing public funds signaled strengthened oversight by the central government. District authorities now knew they would be held accountable for any shortfall (or at least understood that the likelihood of this happening had increased).

\footnotetext{
${ }^{10}$ The main newspapers used were the The New Vision (and its local language editions) and The Monitor.
} 


\section{Assessing the information Campaign: Data}

To assess the effects of increased public access to information on capture of funds a repeat public expenditure tracking survey (PETS) was carried out in 2002. The objective of the repeat survey was twofold. First, it replicated the exercise carried out in 1996, i.e., to measure the difference between the resources disbursed by the central government (intended for primary schools) and the resources actually received by the schools. Second, it collected data on access to information (and access to means for acquiring information) on the grant program, and other variables that may influence the bargaining position of individual schools.

The original 1996 sample consisted of 250 schools, randomly drawn from 18 districts. Two general criteria governed the choice of procedure in selecting the sample of schools to be surveyed from the set of eligible governmentoperated schools (see Reinikka [2001] for details). First, the sample should have a broad regional coverage. Second, it should be representative of the population of schools in the selected districts. A stratified random sample was chosen to account for these considerations. Specifically, it was decided that two or three districts (depending on the number of schools) should be drawn from each of the seven main regions (Northwest, North, Northeast, East, Central, Southwest and West). For each region, two (or three) districts were drawn with a probability proportional to the number of schools in the district, yielding a sample of 18 districts. ${ }^{11}$ In the selected districts, the number of schools visited ranged from 10 to 20, once more depending on the number of schools in the districts. ${ }^{12}$

Due to security concerns, not all schools in the original sample could be re-surveyed in 2002. Specifically, it was decided that two districts (Moroto and Bundibugyo) should be dropped, which reduced the sample by 20 schools. After the data collection had been initiated, one of the districts (Gulu) experienced a major insurgency, and an additional 11 schools had to be dropped. One additional school belonging to the original 1996 sample had ceased to exist, resulting in a final sample of 218 schools. ${ }^{13}$

\footnotetext{
${ }^{11}$ The following 18 districts were selected: Arua, Moyo (Northwest); Apac, Gulu (North); Soroti, Moroto, Kapchorwa (Northeast); Jinja, Kamuli, Pallisa (East); Kampala, Mukono, Mubende (Central); Bushenyi, Kabale (Southwest); and Kabarole, Hoima, Bundibugyo (West).

${ }^{12}$ For both surveys (1996 and 2002), the enumerators were trained and closely supervised by a local research team and survey experts from the World Bank to ensure quality and uniformity of data collection and standards for assessing record-keeping at the schools. In addition to collecting detailed information on financial and in-kind receipts and enrollment data, interviewers made qualitative observations to supplement the quantitative data.

${ }^{13}$ An additional complication was that since the 1996 survey, four districts had been
} 
In addition to collecting detailed information on receipts of funds and enrollment data, a knowledge test of head teachers was also carried out in the 2002 survey.

The 2002 survey also formed the basis for another related research project. To this end, an additional 170 schools from 9 of the original 18 districts were surveyed. The sampling frame for these additional schools was based on the 2001 school census and the sampling procedure was similar to that of the 1996 survey. ${ }^{14}$

Our school-specific measure of capture is grants received (by school $j$ in year $t$ ) as a share of the grants disbursed by the central government to that school. A school's entitlement is a function of the number of P1 to P3 and P4 to P7 grade students. In 1995, the grant formula prescribed that each student in grade P1 to P3 was entitled to 2,500 USh per year, while each student in P4 to P7 was entitled to 4,000 USh. In 2001, the capitation grant was 5,000 USh per year for P1 to P3 students, and 8,100 USh per year for P4 to P7 students. ${ }^{15}$

Release records from the Ministry of Finance (MoF) indicate that this rule was followed, with one exception. Namely, if the districts did not submit documentation in each quarter, release(s) of funds in the following months could be withheld (postponed). ${ }^{16}$ Information obtained by the MoF shows that in the fiscal year 2000/01, on average 93 percent of the approved funds were released, although some districts received significantly less (for example the government withheld 49 percent of the funds to Kyenjojo and 25 percent of the funds to Kayunga). The actual amount disbursed by the central government to districts was confirmed in the surveyed districts. In deriving the capture measure, we adjust for the withholding effect by scaling a school's entitlement with the share of funds actually released by the center to the

split, thus yielding a sample of 22 districts. The new districts are Adjumani, previously part of Moyo, Kyenjojo, previously part of Kabarole, Kayunga, previously part of Mukono, and Katakwi, previously part of Soroti.

${ }^{14}$ Specifically, a stratified random sample was chosen where each district was weighted according to size (number of schools). Thereafter, one district was randomly chosen from each of the seven regions. Two additional districts were then selected from the two larger regions. The nine selected districts were Apac, Arua, Bushenyi, Kabale, Hoima, Kamuli, Pallisa, Mukono, and Soroti. The number of schools to be sampled from each of these 9 districts was proportional to the number of schools in the district.

${ }^{15}$ In real terms, there is no difference. The P1 to P3 entitlement for both 1995 and 2001 was 2.9 U.S. dollars per student in 2001 prices.

${ }^{16}$ Within four weeks after the close of the quarter, the districts were required to submit (i) a progress report for the previous quarter, (ii) a district quarterly report on monitoring visits, (iii) a cumulative progress report, and (iv) a budget request for the forthcoming quarter. 
district during that year.

As with the 1996 survey data, we believe that the grant data collected at the school level adequately reflect what schools actually received. The data were collected directly from the school records and most often, the enumerators could double-check this information from copies of bank cheques received. The concern that head teachers might have underreported the school income in order to extract resources for themselves was perceived as less serious, since each cheque had to be signed by at least two people (the headmaster and the school management committee chairman).

School enrollment data were collected from both the school and the district records. The numbers were very similar (the simple correlation is 0.97). We used the average of these two numbers to calculate each school's aggregate entitlement for the year.

Summary statistics are reported in Tables 1 and 2. As evident, the situation has improved dramatically since the mid 1990s. While only 24 percent of the total yearly grant from the central government reached schools on average in 1995, the average school received more than 80 percent of its entitlement in 2001. Even more striking, while the median school received nothing in the mid-1990s, it received 82 percent of its entitlement in 2001. Thus, the extent of capture fell dramatically. However, for many schools, local capture is still a problem. On average, 20 percent of the schools' entitlements do not reach the schools and about 30 percent of the schools receive less than two-thirds of their entitlements.

Table 1 also depicts the breakdown across regions. The eastern region and, to some extent, the western region have more severe problems of capture. A striking difference from the 1995 data is that the bulk of the variation is now across regions. Specifically, a variance decomposition shows that $11 \%$ of the variation in capture in 2001 is due to variation within regions, while $89 \%$ is due to variation across regions.

\section{THE EFFECTS OF INCREASED PUBLIC ACCESS TO INFORMATION}

A fundamental problem in estimating the effects of increased public access to information arises from the impossibility of observing the same school when it is informed of its entitlements and when it is not informed. The problem is compounded by the fact that the information campaign is characterized as being non-exclusive. Thus, all schools in the 2001 sample could be viewed as treatment schools, although to a varying degree. In addition, potential group effects, as discussed below, make identification even more complex.

We estimate the effects of increased public access to information in three steps. First, we try to establish the extent to which the policy changes, 
including the information campaign, implemented in the late 1990s can account for the large reduction in capture of school funds. Second, we exploit the differences in access to newspapers across schools. Finally, we instrument for exposure to the campaign, using distance to the nearest newspaper outlet as our instrument.

\section{A. Pre-Post COMparison}

To answer the question whether the policy changes implemented in the late 1990s can explain the reduction in capture since 1995, we compare the pre-campaign and post-campaign situation of schools, accounting for the effect of other influences.

Formally, let $s_{j t}$ be funding to school $j$ in period $t$. The average effect of the policy changes $\beta_{1}$ can, under certain conditions, be estimated as

$$
s_{j t}=\beta_{0} x_{j t}^{\prime}+\beta_{1} \sigma_{t}+\mu_{j}+\varepsilon_{j k t},
$$

where $x_{j t}^{\prime}$ is a vector of observable variables that may influence the school's ability to acquire information and voice a complaint to higher authorities (see Reinikka and Svensson [2004]), $\mu_{j}$ is a school-specific effect, and $\sigma_{t}$ is the treatment dummy, taking the value 1 in the post-campaign year 2001 and 0 in the pre-campaign year 1995 .

Table 3 reports the results from estimating (1) using data from 1995 and 2001. In Regression (1), we include the set of bargaining/search variables discussed in Reinikka and Svensson (2004). They show that controlling for school fixed effects, actual spending is highly regressive: schools with children of wealthier parents experience a lower degree of capture. We follow Reinikka and Svensson (2004) and use the mean consumption level across districturban-rural locations as a measure of income (denoted income). ${ }^{17}$

Regression (1) shows that the basic relationship between income and capture remains: schools in better-off communities experience a lower degree of capture. Moreover, we can reject the assumption that the school-specific effects are all equal and that $\mu_{j}$ and the explanatory variables are uncorrelated, thus suggesting that there are important school-specific fixed effects.

Regression $(2)$ adds $\sigma_{2001}$. $\sigma_{2001}$ enters highly significant. The point estimate suggests that the (policy) changes that have occurred since 1995, including the information campaign, has reduced local capture by 60 percentage points, controlling for income. Interestingly, when including the policy

\footnotetext{
${ }^{17}$ The mean consumption level across district-urban-rural is derived from household survey data. See appendix A for details. Note that the district-urban-rural location has no administrative or political boundaries. This will mitigate the danger of the variable picking up processes at the district level that could have a direct bearing on the degree of local capture, rather than income per se.
} 
dummy $\sigma_{2001}$, actual spending is no longer regressive in nature but income neutral. ${ }^{18}$

As stressed above, other changes have occurred in the education sector apart from the newspaper campaign, including improved monitoring and supervision by the central government, increased capitation grants (per student), and a reduction of school fees. It is possible that these additional policy measures, or some other time-varying factor, have influenced the degree of capture. To the extent that these other policy measures had a positive impact on the (average) share of entitled funds reaching the schools, $\beta_{1}$ constitutes a upper bound on the effect of the information campaign. ${ }^{19}$

\section{B. VARIATION IN NEWSPAPER ACCESS}

To estimate the effects of improved public access to information we explore the variation in access to newspapers across schools. Monthly transfers of education funds to the districts have been published in newspapers since 1997. The campaign first covered education funding but has subsequently expanded to include other sectors. Newspapers have also carried numerous stories on misuse of the capitation grant program and frequent articles about schools' entitlements and responsibilities. It seems intuitive that schools with access to newspapers have been more extensively exposed to information on the capitation grant program.

However, there are also some concerns with this approach to estimating the effects. One potential problem is that newspaper access is partly endogenous. Specifically, there may be some unobserved school characteristic correlated with both newspaper access and the efficiency in which the school can articulate its case to the district officials. In practice, there are reasons to believe that this may not be a serious concern. First, schools do not necessarily buy their own newspaper. ${ }^{20}$ Second, in a predominantly rural country like Uganda that lacks adequate transportation infrastructure, access to a newspaper is mainly determined by logistical factors outside the

\footnotetext{
${ }^{18}$ Note that income is constant across schools in a district-rural-urban location. We cannot tell if capture within such a location is regressive or not. Moreover, since income has increased in the late 1990s, including the time dummy $\sigma_{2001}$ will remove an important source of variation to identify the income effect.

${ }^{19}$ In principle, it is also possible that some changes since 1995 may have reduced the schools' bargaining strength, in which case the pre-post estimate may not be the upper bound of the effect.

${ }^{20}$ Sharing of newspapers is not uncommon in poor countries. On average, each copy of the New Vision, one of the main newspapers in Uganda, is read by 10 people, according to the New Vision. School with access to a newspaper may not have access to it every day but reported having access to a newspaper at least once a week. The median school had access to a newspaper 3 days per week.
} 
school/community's control. ${ }^{21}$ Another problem with using newspaper access as an instrument is that a school (i.e., head teacher) may be well-informed about the grant program even if it does not have a newspaper if parents in the community where the school is located have access to one. Finally, newspapers readership (frequency, time spent, etc.) may vary greatly across schools reporting access to at least one newspaper. We deal with these concerns in the following section; this section uses the data on newspaper access as reported in the 2002 survey.

To explore the difference between schools with and without access to newspapers, we employ a difference-in-differences strategy. ${ }^{22}$ The treatment group is thus schools (head teachers) reporting access to at least one main newspaper in 2001, and the control group is schools (head teachers) reporting that they did not have access to a newspaper in 2001.

Let $m$ denote a group of schools, with $m=1$ if the schools belong to the treatment group and $m=0$ otherwise. Let $s_{j 0}$ be funding to a school $j$ without access to newspapers and $s_{j 1}$ funding to a school with access to newspapers. The average funding to the group of schools $m$ without newspapers reporting about the grant program in year $t$ is then $E\left[s_{j 0} \mid t, m\right]$, and the average funding to the group of schools with newspapers in $t$ is $E\left[s_{j 1} \mid t, m\right]$. We observe $E\left[s_{j 1} \mid 2001, m=1\right]$. The difference-in-differences estimator uses the control group to estimate the counterfactual average, $E\left[s_{j 0} \mid 2001, m=0\right]$.

Table 4, panel A, depicts the difference-in-differences estimates. The first column reports funding in 1995, the second column reports funding in 2001, and the third column reports the difference between them. The rows give averages (and standard errors) for the treatment group, the control group, and the differences between them. As is evident, in 1995, the treatment and the control group suffered just as much from local capture. In fact, the treatment group received less funds than the control group, although the difference is not significant. This finding suggests that the treatment group did not have any other specific characteristics (apart from access to newspapers) which increased their capability to claim funds in 1995. From 1995 to 2001, there is a large drop in leakage in both groups, which is consistent with the pre-post findings reported above. However, the reduction in leakage is significantly higher in the treatment group. The difference-in-differences estimate is 13.8 and is significant at the 5-percent level. Thus, schools with access to newspapers and thus more extensively exposed to public information about the grant program, on average increased their funding by 13.8 percentage points

\footnotetext{
${ }^{21}$ See Bjorkman (2003).

${ }^{22}$ Note that our approach differs from the standard difference-in-differences model (see for instance Angrist and Krueger [1999]), since the groups are defined according to ex post characteristics (access to a newspaper).
} 
more than the schools that lacked access to newspapers.

The identifying assumption in the difference-in-differences model is that in the absence of the campaign, the reduction in capture would not have been systematically different in the group of schools with and without access to newspapers. However, it is possible that the funding shares would have evolved differently across groups if the groups differed in other dimensions, for example in income. Table 5, Regression (1), depicts the regression version of the difference-in-differences method. In Regression (2), we add income as additional control. The difference-in-differences estimate remains unchanged.

Another way to test this assumption is to compare the trend in outcomes before the campaign; i.e., during the period 1991-95. In Table 4, Panel B, we present this control experiment. Although the amount of spending reaching the schools improved over the period, the trends do not differ systematically across the two groups. The differences-in-differences estimate is in fact even negative, although insignificantly different from 0 . These results provide some suggestive evidence that the results reported in panel A are not driven by some unobserved variables that cause funding to schools to evolve differently across treatment and control groups.

\section{NeWspapers AND KNOWLEDGE}

The maintained assumption in the previous section is that head teachers with access to a newspaper have been more extensively exposed to the campaign, and therefore have better information about the timing of disbursements and the workings of the grant program. In this section, we use data based on a simple knowledge test of head teachers to test this assumption.

Table 6 reports a set of regressions where the explanatory variable is access to newspapers and the dependent variables are test scores indicating to what extent the head teacher correctly answered the question(s) reported in the top row. That is,

$$
q_{j}=\delta_{0} x_{j}^{\prime}+\delta_{1} m_{j}+\varepsilon_{j},
$$

where $m_{j}$ is a binary variable denoting access $(=1)$ to a newspaper and $q_{j}$ is test score of the head teacher in school $j$. The second and third last rows in Table 6 report the range of possible scores and average test score in the sample population, respectively.

Regression (1) shows that schools with newspapers are better informed about the formula for deriving the capitation grant. They are also better informed about the timing of releases of funds by the central government (Regression (2)). The dependent variable in Regression (3), info, is the sum of the dependent variables in Regressions (1) and (2). Schools with access 
to newspapers are more informed in general about the workings of the grant program.

One concern with the test score results in columns 1-3 is that head teachers with access to newspapers are high-ability types and thus more knowledgeable in general. A way to test this is to compare their knowledge in other areas. These test results are presented in Regressions (4)-(6). In Regression (4), the dependent variable is knowledge about news events and people that appeared in the newspapers at the time of the survey in 2002 . As expected, head teachers with access to a newspaper are significantly more likely to score high on this variable than head teachers without access to a newspaper. ${ }^{23}$ However, we find no significant difference between the two types of head teachers in their knowledge of local affairs (Regression (5)), ${ }^{24}$ or knowledge of general (sociopolitical) issues typically not reported in the papers (Regression (6)). ${ }^{25}$

While not providing any comprehensive assessment of head teachers' knowledge and abilities, the test scores findings reported in Table 6 suggest that it is information on the grant program disseminated through newspapers rather than some unobserved characteristic (e.g., ability) correlated with newspaper access that accounts for the observed effects.

\footnotetext{
${ }^{23}$ We asked the respondents if they could identify the following individuals: (a) Winnie Byanyima (outspoken MP and the wife of a former presidential candidate), (b) Thabo Mbeki (President of South Africa), (c) Bono (rock singer who was touring Africa that time), (d) George W. Bush (President of the United States), and (e) Charles OnyangoObbo (outspoken editor of The Monitor). We also asked if the respondent could name the (f) Minister of Education (Hon. Makubuya), (g) Minister of Finance (Hon. Ssendaula), and (h) Prime Minister (Hon. Nsibambi). The head teachers with access to newspapers were significantly more likely to respond correctly to each individual question (except the question on President Bush for which we found no significant difference). The variable "knowledge about recent news events" is the average score on these eight questions, where a correct answer is coded as 1 and an incorrect answer is coded as 0 .

${ }^{24}$ We asked if the respondents could name the (a) District Education Officer, (b) Chief Administrative Officer (in the district), (c) LC 5 Chairman (Local Council 5 chairman), (d) LC 3 Chairman, and (e) their representative in Parliament. The two types of schools (head teachers) were as likely to repond correctly to each of these questions. The variable "knowledge about local affairs" is the average score on these five questions, where a correct answer is coded as 1 and an incorrect answer is coded as 0 .

${ }^{25}$ Respondents were asked the following questions: what is the (a) largest newspaper by circulation in Uganda (The New Vision), (b) location of East African Parliament (Arusha, Tanzania), (c) MTN (cellular/mobile phone provider), (d) month when the government's budget is presented to Parliament (June), (e) number of districts in Uganda (56), (f) number of members in Parliament (305). The two types of schools (head teachers) were as likely to repond correctly to each of these questions. The variable "general political knowledge" is the average score on these six questions, where a correct answer is coded as 1 and an incorrect answer is coded as 0 .
} 


\section{USING VARIATION IN DISTANCE TO THE NEAREST NEWSPAPER OUTLET TO INSTRUMENT FOR EXPOSURE TO THE CAMPAIGN}

The findings presented above show that, since the information campaign started, schools (head teachers) with access to newspapers experienced a significantly larger reduction in capture. These schools are also more informed about the workings of the grant program, but on test scores of general ability they look similar to the group of schools without newspapers. However, as stressed above, using variation in newspaper access to identify the effects of increased access to information as a tool to reduce capture and corruption may be problematic. First, newspaper access is partly endogenous. Second, head teachers may be informed about the grant program by parents with access to newspapers. Third, within the group of newspaper schools, there is variation in how regularly the head teacher has access to a newspaper.

To circumvent these potential problems, we instrument for exposure to the information campaign using distance to the nearest newspaper outlet. ${ }^{26}$ For distance to the nearest newspaper outlet to serve as a legitimate instrument for exposure to the campaign, it must affect the school's exposure to new information about the grant program but have no direct effect on the its ability to claim funds from the district. Distance to the nearest newspaper outlet captures the cost and ease of accessing a newspaper. Thus, it is most likely correlated with both the likelihood that the head teacher and the parents in the school community have access to a newspaper (and thereby correlated with the school's and the community's likelihood of being exposed to new information). At the same time, in a sample of predominantly rural schools, we would not expect a direct link between head teacher (parent) characteristics and newspaper outlet. While "high ability" types (teachers and parents) may choose to migrate to urban centers (e.g., the capital Kampala or district capitals), it is hard to imagine that a newspaper outlet is an important determinant of the migration decisions. Evidence in favor of our identification strategy is presented in Table 6 and Table 7.

In Table 7, Regression (1), we estimate the probability of the head teacher having access to newspapers. Being located near a newspaper outlet has a strong and significant effect on the probability of the head teacher having access to newspapers. In Regression (2), we add income. The result remains intact.

Table 6, Panel B, replicates the head teacher knowledge-test regressions, using distance to the nearest newspaper outlet instead of newspaper access (as reported by head teachers) as an explanatory variable. Distance to the

\footnotetext{
${ }^{26}$ Geographical characteristics, including distance, have been used in other areas to identify causal effects, see for instance Card [1993] and McClellan et al. [1994].
} 
nearest newspaper outlet has a strong negative effect on knowledge about the grant formula and timing of releases of funds from the center (Regressions (1)-(3)). Head teachers serving in schools close to a newspaper outlet score significantly higher on the knowledge test about recent news events (Regression (4)). However, distance to the nearest newspaper outlet is uncorrelated with the two test-score-based measures of ability; i.e., knowledge about local affairs and general political knowledge (Regressions (5)-(6)).

The relationship between information about the grant program and proximity to a newspaper outlet is significant and remains intact once controlling for income (Regression (4), Table 7). In Regression (5) we add proximity to the district headquarters and distance to nearest bank branch as additional controls. The district head quarter is typically situated in the district capital. Proximity to a bank branch is a proxy of the distance to nearest urban center. As evident, once controlling for proximity to nearest newspaper outlet, distance to the district capital and urban center have no effect.

Regression (6), Table 7, suggests that distance to the nearest newspaper outlet has an independent effect on the school's knowledge about the grant program; it enters highly significant, suggesting that the community link discussed above is important. Controlling for distance, the coefficient on newspaper access is reduced by 35 percent.

E. Instrument VARIABLE ESTIMATES FOR IMPACT OF PUBLiC ACCESS TO INFORMATION ON CAPTURE OF FUNDS

Table 8 presents reduced-form coefficients of the distance to the nearest newspaper outlet variable on the change in capture of funds. Specifically, we estimate

$$
s_{j t}=\beta_{0} x_{j t}+\beta_{1} \text { distance }_{j}+\beta_{2} \sigma_{t}+\beta_{3} \sigma_{t} \text { distance }_{j}+\mu_{j}+\varepsilon_{j t},
$$

where $\beta_{3}$ is the reduced form estimate. We can difference away the schoolspecific effects. Thus we estimate

$$
\Delta s_{j k}=\beta_{0} \Delta x_{j k}+\beta_{2} \sigma_{2001}+\beta_{3} \sigma_{2001} \text { distance }_{j}+\Delta \varepsilon_{j k}
$$

Two sets of regressions are reported in the upper and lower panels of Table 8. In Panel A, we estimate the effect over the information campaign period; i.e., $\sigma_{t}$ takes the value 1 in the post-campaign year 2001 and 0 in the pre-campaign year 1995. The control experiment reported in Panel B estimates the effects during the five-year period prior to the campaign (i.e., $\sigma_{t}$ takes the value 1 in 1995 and 0 in 1991).

As reported in Panel A, there is a strong relationship between distance to the nearest newspaper outlet and reduction in capture since the newspaper 
campaign started. This result contrasts sharply with the changes in capture rates in the five-year period prior to the campaign, as reported in Panel B.

Table 9, columns 1-2 report the structural regression

$$
\Delta s_{j k}=\gamma_{0} \Delta x_{j k}+\gamma_{1} \sigma_{2001}+\gamma_{2} i n f o_{j k}+\Delta \varepsilon_{j k}
$$

The predicted school-specific outcomes, $\widehat{\operatorname{info}}_{j}$, are attributed to distance ${ }_{j}$, and hence reflect factors outside the school's (community's) control. Note that we use all sample information (388 observations), reported in Table 7 , columns (3), to derive the generated regressor $\widehat{i n f o}_{j}$.

Schools more extensively exposed to the newspaper campaign; i.e., the more informed schools, experience a significantly larger reduction in local capture since the campaign started. ${ }^{27}$ We report both OLS standard errors (in parenthesis) and bootstrapped standard errors (in brackets). The OLS standard errors are biased because they ignore the uncertainty in the estimated effect of distance ${ }_{j}$ on info $_{j}$ in the first-stage regression. In practise, this seems to be less of a problem since the two standard error estimates are close.

The quantitative effect of improved access to public information is large. The IV estimate implies that a one standard deviation increase in info results in a 1.1 standard deviation increase in spending reaching the schools (i.e., 44.2 percentage points increase in funding reaching the school between 1995 and 2001).

\section{F. Group effects: Some suggestive evidence}

So far we have analyzed the effects of improved public access to information through the direct channels from a more informed school and community. However, there are reasons to believe that exposure to the newspaper campaign may be correlated across schools within the district. For example, there may be externalities in learning about the grant program. ${ }^{28}$ Specifically, teachers may learn from their peers. Local capture may also be influenced by an exogenous (contextual) group effect. This would be the case if the local officials cannot distinguish whether or not a school is informed (has access to newspapers) about its entitlement. Then, funding to school $j$ in district $k$ would depend on the share of schools being informed in the district rather

${ }^{27}$ The fit of first-stage regression (i.e., (2) with info as dependent variable) is good. The $F$-test of the significance of distance in the first-stage regression is 11.8 with p-value of 0.00 .

${ }^{28}$ There are several studies from developing countries that have shown that learning externalities are quantitatively important in, for example, the adoption of new technologies. See for instance Besley and Case [1994] and Foster and Rosenzweig [1995]. 
than the individual school's knowledge. In Appendix B, we present a simple model that highlights these two types of group effects.

In this section, we provide some suggestive evidence of group effects. As discussed in Appendix B, the two group mechanisms are complements and empirically we cannot distinguish between them. What we can do is test if the degree of capture for school $j$ in district $k$ is influenced by the aggregate or average exposure to the newspaper campaign in the district.

A first test of this is reported in column (2), Table 9. In column (2), we add the average exposure to the newspaper campaign in the district, defined as the average distance to the nearest newspaper outlet in the district (avdistance $_{j k}$ ), to the first stage regression (2). ${ }^{29}$ Both proximity to a newspaper outlet and the average distance to the nearest newspaper outlet in the district enter significantly, suggesting that school $j$ :s awareness of its entitlements is affected by the degree of exposure to the newspaper campaign of other schools in the district. This is consistent with there being important externalities in learning about the grant program across peers.

Column (3) presents the IV estimate of the effects of improved public access to information, using both distance $_{j k}$ and avdistance $_{j k}$ as instruments. With both distance $_{j k}$ and avdistance $_{j k}$ as controls, the predicted schoolspecific information about the grant program is more precisely estimated (the $F$-statistic of their joint significance in the first-stage regression is 15.9 and is highly significant). This shows up in the structural equation since the standard errors of $i n f o_{j}$ are smaller. Since the model is now overidentified, we can also test the validity of the instruments; i.e., that the instruments are uncorrelated with the error process in (5). As reported in the second row from the bottom, we cannot reject the null hypothesis that the instruments satisfy the orthogonality conditions.

In column (4), we separate between the effects of school-specific information and the average information across schools in the district. $\widehat{\inf }_{j k}$ is the predicted school-specific outcomes attributed to distance $_{j k}$, and avinfo $_{j k}$ is the average outcomes attributed to avdistance $_{j k}$. Both information variables enter significantly. While the coefficient on avinfo is larger, we cannot reject the hypothesis that the coefficients are equal. The IV estimates in column (4) suggest that a one standard deviation increase in info [avinfo] results in a $0.73[0.46]$ standard deviation increase in spending reaching the schools. These findings are consistent with the contextual group effect mechanism discussed in appendix B. However, the findings are suggestive, since in column (4) we allow the average exposure to the newspaper campaign in the district

\footnotetext{
${ }^{29}$ Avdistance $_{j k}=\frac{1}{N_{k}-1} \sum_{n_{i} \neq n j}^{N_{k}-1}$ distance $_{i}$, where $N_{k}$ is the number of schools in district $k$, and distance $_{j}$ is the distance to nearest newspaper outlet of school $j$.
} 
(avdistance $_{j k}$ ) to only influence the reduction in capture through improved access to information about the grant program of all other schools in the district. As reported in column (2), the average exposure to the newspaper campaign in the district may also (through learning externalities) influence individual schools knowledge about the program.

\section{G. Robustness tests}

We run a number of additional robustness tests on the results reported above, including dropping, one at the time, all observations from each region in Uganda to see whether the results are driven by any region-specific effects. The IV estimates of the effects of being better informed range from 52.3 (when schools in the northern region are dropped) to 70.1 (when schools in the central region are dropped) and are highly significant. We also dropped the schools that received more than 100 percent of their entitlements in a given year. This raised the IV estimate slightly. Finally, we added additional controls in all specifications, including a measure of the quality of the school leadership (measured as the share of qualified teachers) and school size. All results remain intact. Since both school size and staff composition may be endogenous and since we lose a few observations when including these additional controls, we leave them out of the base specifications.

\section{Conclusion}

Through a relatively inexpensive policy action - the provision of mass information - Uganda dramatically reduced district-level capture of a public program aimed at increasing primary education. Poor people who were less able than others to claim their entitlement from district officials before the campaign, but just as likely in 2001, benefited most.

In this paper, we exploit the public information campaign to assess the effects of increased public access to information as a tool to reduce capture and corruption of public funds. We use distance to the nearest newspaper outlet as an instrument for exposure to the campaign. Proximity to a newspaper outlet is positively correlated with the head teachers' knowledge about rules governing the grant program and the timing of releases of funds from the center, but uncorrelated with test scores of general ability. A strong (reduced-form) relationship exists between distance to the nearest newspaper outlet and reduction in capture since the newspaper campaign started. The post-campaign reduction in capture contrasts sharply with the pattern prior to the newspaper campaign. Instrumenting for head teachers' knowledge about the grant program, we find that public access to information is a powerful deterrent to local capture. 
A number of other public expenditure tracking surveys show that capture is not a problem specific to Uganda above. Local capture in education programs appears to be a serious problem in most African countries where similar studies have been implemented, including Ghana, Tanzania, and Zambia (Reinikka and Svensson [2004]). A common denominator in these education programs is that, at best, users have limited knowledge about the public funding they are entitled to.

At present, several countries have, or are in the process of initiating a capitation grant program (for example Cambodia, Kenya, and Tanzania). The results presented in this paper suggest the value of making public information available to the beneficiaries (parents and teachers) about the school-funding program.

\section{REFERENCES}

Ades, Alberto, and Rafael Di Tella. 1997. "National Champions and Corruption: Some Unpleasant Interventionist Arithmetic." The Economic Journal 107(443): 1023-42.

Ades, Alberto, and Rafael Di Tella. 1999. "Rents, Competition, and Corruption." American Economic Review 89(4): 982-93.

Ahrend, Rudiger. 2002. "Press Freedom, Human Capital, and Corruption." Working Paper 2002-11. Delta (Ecole Normale Supérieure), Paris.

Angrist, Joshua D., and A. B. Krueger. 1999. "Empirical Strategies in Labor Economics." In Orley C. Ashenfelter and David E. Card, eds., Handbook of Labor Economics, Vol. 3A. Amsterdam: Elsevier Science Pub. Co.

Banerjee, Abhijit, and Ruimin He. 2003. "The World Bank of the Future." American Economic Review 93(2): 39-44.

Bayart, Jean-François. 1993. The State in Africa: The Politics of the Belly. London; New York: Longman.

Besley, Timothy, and Robin Burgess. 2002. "The Political Economy of Government Responsiveness: Theory and Evidence From India." The Quarterly Journal of Economics 177(4):1415-51.

Besley, Timothy, and Ann Case. 1994. "Unnatural Experiments? Estimating the Incidence of Endogenous Policies." Working Paper 4956. National Bureau of Economic Research, Cambridge, Mass.

Björkman, Martina. 2003. "Public Funding in the Educational Sector and Its Effect on Test Scores." Department of Economics, Stockholm University. Processed.

Brunetti, Aymo, and Beatrice Weder. 2003. "A Free Press is Bad News for Corruption." Journal of Public Economics 87(7-8): 1801-24. 
Card, David. 1993. "Using Geographical Variation in College Proximity to Estimate the Return to Schooling." NBER Working Paper Series No. 3383.

Dehn, Jan, Ritva Reinikka, and Jakob Svensson. 2003. "Survey Tools for Assessing Performance in Service Delivery." In François Bourguignon and Luiz A. Pereira da Silva, eds., The Impact of Economic Policies on Poverty and Income Distribution: Evaluation Techniques and Tools. A copublication of the World Bank and Oxford University Press.

Di Tella, Rafael, and Ernesto Schargrodsky. 2003. "The Role of Wages and Auditing During a Crackdown on Corruption in the City of Buenos Aires." Journal of Law and Economics XLVI (1): 269-92.

Djankov, Simeon, Caralee McLiesh, Tatiana Nenova, and Andrei Shleifer. 2003. "Who Owns the Media?" Journal of Law and Economics XLVI (2): $341-81$.

Foster, Andrew, and Mark R. Rosenzweig. 1995. "Learning By Doing and Learning from Others: Human Capital and Technical Change in Agriculture." Journal of Political Economy 103:1176-1209.

Hellman, Joel S., Geraint Jones, Daniel Kaufmann, and Mark Schankerman. 200a. "Measuring Governance, Corruption, and State Capture." Policy Research Working Paper 2312. World Bank, Development Research Group, Washington, D.C..

Hellman, Joel S., Geraint Jones, Daniel Kaufmann. 2000b. "Seize the State, Seize the Day: State Capture, Corruption, and Influence in Transition."Policy Research Working Paper 2444. World Bank, Development Research Group, Washington, D.C.

Jeppsson, Anders. 2001. "Financial Priorities under Decentralization in Uganda." Health Policy and Planning 16(2): 187-192.

Manski, Charles F. 1993. "Identification of Endogenous Social Effects: The Reflection Problem." Review of Economic Studies 60: 531-42.

Mauro, Paulo. 1995. "Corruption and Growth." The Quarterly Journal of Economics 110: 681-12.

McClellan, Mark, Barbara J. McNeil, and Joseph P. Newhouse. 1994. "Does More Intensive Treatment of Acute Myocardial Infarction in the Elderly Reduce Mortaility?" Journal of the American Medical Association 272 (11): 859-66.

McPake, Barbara, Delius Asiimwe, Francis Mwesigye, Mathias Ofumbi, Pieter Streefland, and Asaph Turinde. 1999. "The Economic Behavior of Health Workers in Uganda: Implications for Quality and Accessibility of Public Health Services." Social Science and Medicine 49(7): 849-65.

Persson, Torsten, Guido Tabellini, and Francesco Trebbi. 2001. "Electoral Rules and Corruption." Working Paper 8154. National Bureau of Eco- 
nomic Research. Cambridge, Mass.

Reinikka, Ritva. 2001. "Recovery in Service Delivery: Evidence from Schools and Health Centers." In Ritva Reinikka and Paul Collier, eds., Uganda's Recovery: The Role of Farms, Firms, and Government. Regional and Sectoral Studies. Washington, D.C.: World Bank.

Reinikka, Ritva, and Jakob Svensson. 2003. "Survey Techniques to Measure and Explain Corruption." Policy Research Working Paper 3071. World Bank, Development Research Group, Washington, D.C.

Reinikka, Ritva, and Jakob Svensson. 2004. "Local Capture: Evidence from a Central Government Transfer Program in Uganda." The Quarterly Journal of Economics 119(2).

Stasavage, David. 2003. "On the Role of Democracy in Uganda's Move to Universal Primary Education." Background paper for the World Development Report 2004: Making Services Work for Poor People. Washington, D.C.: World Bank.

Strömberg, David. 2003. "Mass Media and Public Policy." European Economic Review 45(4-6): 652-63.

Strömberg, David. 2004. "Radio Impact on Public Spending." The Quarterly Journal of Economics 119(1).

Svensson, Jakob. 2000. "Foreign Aid and Rent-seeking." Journal of International Economics 51(2): 437-461.

Svensson, Jakob. 2003. "Who Must Pay Bribes and How Much? The Quarterly Journal of Economics 118 (1): 207-30.

Thomas, Melissa. 1998. "Corruption and Political Finance in Africa." PREM Seminar Series. World Bank, Washington, D.C.

Thomas, M. 1999. "The Incentive Structure of Systemic Corruption." World Bank, Washington, D.C. Processed.

Treisman, Daniel. 2000. "The Causes of Corruption: A Cross-National Study." Journal of Public Economics 76(3): 399-457. 


\section{APPENDIXES}

\section{APPENDIX A: VARIABLE DEFINITION AND DATA DESCRIPTION}

$\sigma_{2001}=$ treatment dummy taking the value 1 in the post-information period 2001 and 0 in the pre-information period 1995.

distance to nearest newspaper outlet $=$ distance to the nearest newspaper outlet in kilometers $(\log )$ (source: survey data).

income $=$ mean consumption level in the district-urban-rural location constructed from the 1995 and 1999/2000 Uganda National Household Surveys (source: constructed using data from the 1995 and 1999/2000 Uganda National Household Survey).

info $=$ sum of the test scores "knowledge about the formula for deriving the capitation grant" $[0,1]$ and "knowledge about the timing of releases of funds by the central government" $[0,1]$.

newspaper $=$ dummy taking the value 1 if the school has access to a national newspaper, 0 otherwise (source: survey data).

school size $=$ number of students in P1-P7 (source: survey data).

$s_{j t}=$ capitation grant received as a share of what should have been received, adjusted for withheld funds by the Ministry of Finance (MoF) and for lower enrollment rates as reported by the central government (source: survey data, official statistics from MoF)

share of qualified teachers $=$ share of qualified teachers to total number of teachers (source: survey data).

\section{Appendix B: A simple model of the effects of the Campaign}

Consider a public official in a district who receives funds $\bar{s}$ per school from the government. There are $J>1$ schools in the district. The official is in charge of disbursing the funds to the schools. He may capture part (or all) of the funds, but then runs the risk of being investigated. If investigated, the official will be fired (conditional on parts of the fund being captured). A fired official cannot keep any captured funds. An investigation can be initiated by the central government. Assume there to be a probability $\rho$ that an audit (monitoring visit) will take place in school $j$ and conditional on the audit, an investigation will be initiated with probability $m\left(s_{j}\right)$, where $m^{\prime}\left(s_{j}\right)<0, m^{\prime \prime}\left(s_{j}\right)>0, m(\bar{s})=0$, and $m(0)=1$. We thus assume the likelihood of an investigation to be a function of how large parts of the centrally disbursed funds reaches the school. The probability function is depicted in Figure 1.

Individual schools may also initiate an investigation (by voicing a complaint to higher authorities). The probability of a school voicing a complaint depends on both the amount of money the school is receiving and whether it is aware of its entitlements. Specifically, we assume the likelihood of school $i$ initiating an investigation to be $\theta_{j} m\left(s_{j}\right)$, where $\theta_{j} \in[0,1]$ captures the school's knowledge 


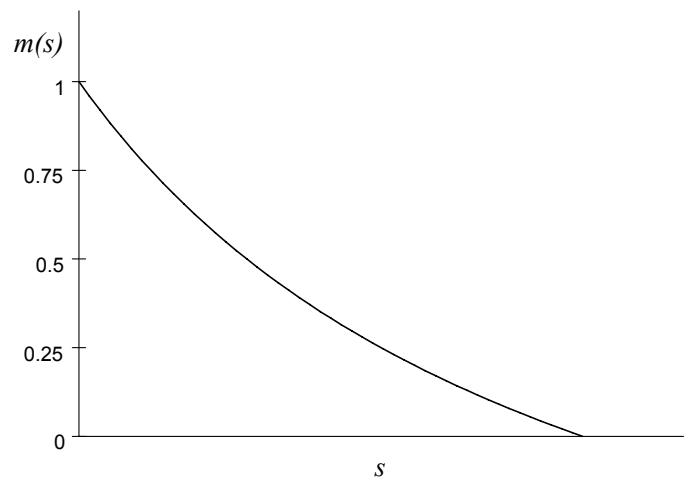

Figure 1: Probability of an investigation as a function of $s_{j}$.

about its entitlement. ${ }^{30}$

We start by assuming that the official can observe $\theta_{j}$.

The probability of an investigation of capture of funds from school $j, p_{j}$, is

$$
p_{j}=\rho m\left(s_{j}\right)+(1-\rho) \theta_{j} m\left(s_{j}\right)=\gamma_{j} m\left(s_{j}\right),
$$

where $\gamma_{j} \equiv \rho+(1-\rho) \theta_{j}{ }^{31}$

The public official is an expected rent-maximizer. Thus, he maximizes capture taking (6) into account. The expected rents are

$$
\Pi=(1-P)\left[J \bar{s}-\sum_{j=1}^{J} s_{j}\right]
$$

where $P=1-\prod_{j=1}^{J}\left(1-p_{j}\right)$ is the likelihood of an investigation being initiated in at least one school, and the second term is aggregate capture.

Solving the official's maximization problem yields $J$ first-order conditions (for $\left.s_{1}, \ldots s_{J}\right)$,

$$
-\gamma_{j} m^{\prime}\left(s_{j}\right)\left(J \bar{s}-\sum_{i=1}^{J} s_{i}\right)-\left[1-p_{j}\right]=0 \quad j=1,2 \ldots J .
$$

\footnotetext{
${ }^{30}$ Note that this assumption implies that for a fully informed school (i.e., $\theta_{j}=1$ ), the likelihood of an investigation is the same as for an audited school. It is straightforward to relax the assumption that the probability of the government initiating an investigation, $m\left(s_{j}\right)$, is the same as the probability of the school doing so. The qualitative results remain intact.

${ }^{31}$ Note that if an audit takes place, we assume that the school will not initiate its own investigation.
} 
The first-order conditions illustrate the tradeoff facing the public official. Reducing capture to school $j$ by one unit increases the chances of no investigation taking place and thus that the official can keep his captured funds $\left(J \bar{s}-\sum_{i=1}^{J} s_{i}\right)$, the first term in $(8)$, but also lowers the expected returns by $\left(1-p_{j}\right)$ units.

Total differentiating the first-order condition, we can show that local capture of funding to school $j$ is a negative function of external supervision (or audit) $\rho$, and a negative function of the school-specific effect $\theta_{j} .{ }^{32}$ Moreover, an increase in school $j$ :s knowledge of the grant program reduces the funding to school $k$, even if school $k$ is informed. The intuition is as follows. If a school becomes more informed, this forces the official to increase that school's funding. As a result, total capture, $\left(J \bar{s}-\sum_{i=1}^{J} s_{i}\right)$, falls. This, in turn, reduces the return to honest behavior (first term in (8)) and, as a result, more funds will be captured from school $k$.

Consider instead a situation in which the official does not know the extent to which each individual school is aware of its entitlement, i.e., $\theta_{j}$ is private information, but the official has knowledge about the overall distribution of informed schools. We can capture this by assuming there are two types of schools, more informed schools (type $\bar{\theta}$ schools) and less informed schools (type $\underline{\theta}$ schools), where $\bar{\theta}>\underline{\theta}$. The official knows that a share $\alpha \leq 1$ of the schools are of type $\bar{\theta}$.

The probability of an investigation of capture of funds from school $j, p_{j}$, is now

$$
p_{j}=\gamma m\left(s_{j}\right),
$$

where $\gamma \equiv \rho+(1-\rho)[\alpha \bar{\theta}+(1-\alpha) \underline{\theta}]$. Solving the official's maximization problem yields first-order conditions,

$$
-\gamma m^{\prime}\left(s_{j}\right)\left(J \bar{s}-\sum_{i=1}^{J} s_{i}\right)-\left[1-p_{j}\right]=0 \text { for } j=1,2 \ldots J
$$

In this second version of the model, external supervision (or audit) has a similar effect as in the full-information version. However, a school's individual knowledge about its entitlements $\theta_{j}$ does not influence the outcome. Instead, funding to school $i$ depends on the share of schools being informed. It is straightforward to show that $d s_{j} / d \alpha>0$, i.e., the more informed schools in a district the more funding to each individual school. In Manski's [1993] terminology, local capture is driven by an exogenous (contextual) group effect. ${ }^{33}$

So far we have assumed that there are no externalities in learning about the grant program. However, it seems reasonable to assume that school staff learn

\footnotetext{
${ }^{32}$ Proofs available upon request.

${ }^{33}$ There is an exogenous (contextual) group effect since there is a causal relationship between the characteristics of the peer group members and outcome (average access to newspapers affects the official's maximization program and thus each school's funding).
} 


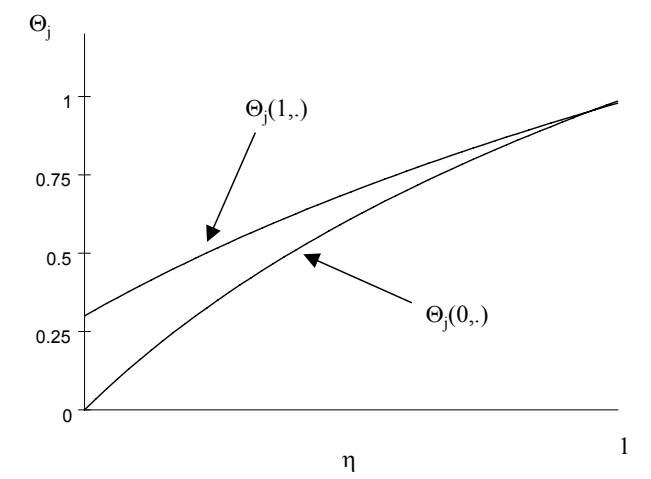

Figure 2: Knowledge $\Theta_{j}\left(\eta_{j}, \eta\right)$ as function of $\eta$.

from their peers or friends. ${ }^{34}$ A simple way to introduce externalities in information across schools is to assume that $\theta_{j}$ is a non-negative function of both a school-specific effect $\eta_{j}$ (e.g., access to a newspaper) and the stock of knowledge in the district (e.g., average newspaper access in the district) $\eta$. Specifically, let $\eta_{j}=\{0,1\}$ where $\eta_{j}=1$ (0) indicates that the school has (has not) access to a newspaper and $\bar{\eta}=(1 / J) \sum_{i=1}^{J} n_{i}$. A school's knowledge about its entitlement is now $\theta_{j}=\Theta_{j}\left(\eta_{j}, \eta\right)$, where $d \Theta_{j} / d \eta_{j} \geq 0, d \Theta_{j} / d \eta \geq 0$, and $\Theta_{j}(1, \eta) \geq \Theta_{j}(0, \eta)$. The knowledge function $\Theta_{j}\left(\eta_{j}, \eta\right)$ is illustrated in Figure 2.

If $\theta_{j}$ is private information, introducing externalities will not change the relative distribution of school grants across schools, although it will positively affect the amount each school receive. That is, $s_{j}=s$ for all schools, but the amount received will be higher as aggregate knowledge increases. In this case, local capture is driven both by an exogenous (contextual) group effect and an endogenous group effect (Manski [1993]).

If local officials can partly or fully observe each school's knowledge about the grant, introducing externalities will affect, and possibly change the sign of, $d s_{k} / d \theta_{j}$. In the example considered above, if $\theta_{j}=\Theta_{j}\left(\eta_{j}, \eta\right)$, an increase in school $j$ :s knowledge about the grant may now (if the externalities are strong enough) even increase funding to school $k$. In this case, there are two countervailing forces. As before, if a school becomes more informed this forces the official to increase that school's funding. As a result, total capture, $\left(J \bar{s}-\sum_{i=1}^{J} s_{i}\right)$, falls. This in turn reduces the return to behaving honestly (first term in (8)) and as a result more funds will be captured from school $k$. However, a higher $\eta_{j}$ also raises the marginal return of reducing capture (first term in (8)) and reduces the expected marginal

\footnotetext{
${ }^{34}$ There are several studies from developing countries that have shown that learning externalities are quantitatively important in, for example, the adoption of new technologies. See for instance Besley and Case (1994) and Foster and Rosenzweig (1995).
} 
loss of channeling more funds to the schools (second term in (8)). Both these forces will tend to increase funding to school $k$.

More generally, if the official observers a signal of each school's knowledge, for instance the official observes if the school has access to a newspaper or not, and learning spillovers are important, he will rationally induce that all schools' knowledge about the grant in the district have increased. If the knowledge function is as depicted in Figure 2, the higher $\eta$, the more funding to each individual school and the smaller the difference between $\eta_{j}=1$ and $\eta_{k}=0$ schools. 
Table 1. Summary information on capture (in percent)

\begin{tabular}{lcccccc}
\hline \hline & Mean & Median & St. dev. & Max & Min & Obs \\
\hline All schools & & & & & & \\
1995 & 23.9 & 0 & 35.1 & 109.8 & 0 & 229 \\
2001 & 81.8 & 82.3 & 24.6 & 177.5 & 9.0 & 217 \\
\cline { 2 - 6 } & \multicolumn{2}{c}{ Mean (1995) } & Mean (2001) & & & \\
\hline Regions & & & & & \\
Central & 24.3 & 92.8 & & \\
North & 26.7 & 102.4 & & \\
Northwest & 11.2 & 90.3 & & & \\
West & 24.0 & 71.6 & & & \\
Southwest & 21.1 & 83.3 & & & \\
East & 20.1 & 62.4 & & & \\
Northeast & 36.0 & 73.4 & & & \\
\hline \hline
\end{tabular}

a. Grants received as share of entitled grants.

Table 2. Summary statistics on school characteristics

\begin{tabular}{lccc}
\hline \hline & Median & Mean & Std.dev. \\
\hline 1995 & 449 & 531 & \\
School size (no. of students) & 7,315 & 7,785 & 375 \\
Income & 0.88 & 0.79 & 0.25 \\
Share of qualified teachers & & & \\
2001 & 855 & 952 & 477 \\
School size (no. of students) & 9,001 & 10,322 & 5,078 \\
Income(Ush) & 1 & 0.91 & 0.17 \\
Share of qualified teachers & 1 & 0.63 & 0.44 \\
Newspaper & 9 & 15.3 & 33.3 \\
Distance to newspaper outlet $(\mathrm{km})$ & 15.8 & 15.3 & 8.5 \\
Average distance to NP outlet $(\mathrm{km})$ & &
\end{tabular}


Table 3. Pre-post outcomes

\begin{tabular}{|c|c|c|}
\hline Specification & (1) & (2) \\
\hline Income & $\begin{array}{c}0.012^{* * *} \\
(.002)\end{array}$ & $\begin{array}{l}-0.002 \\
(.002)\end{array}$ \\
\hline$\sigma_{2001}$ & & $\begin{array}{l}60.3^{* * *} \\
(4.28)\end{array}$ \\
\hline School fixed effects & yes & yes \\
\hline Adj. $\mathrm{R}^{2}$ & 0.10 & 0.56 \\
\hline Schools & 247 & 247 \\
\hline Observations & 446 & 446 \\
\hline \multicolumn{3}{|c|}{$\begin{array}{l}\text { a. Dependent variable is grants received as share of entitled grants. } \\
\text { b. Controls are share of qualified teachers and number of students. } \\
\text { c. Robust standard errors in parenthesis. } \\
\text { d. }{ }^{* * *}[* *](*) \text { denote that the parameter is significantly different } \\
\text { from zero at the } 1[5](10) \text { percent levels. }\end{array}$} \\
\hline
\end{tabular}


Table 4. Difference-in-differences estimates of the effects of having a newspaper on capture and control experiment

\begin{tabular}{lccc}
\hline Group & \multicolumn{3}{c}{ Year } \\
\cline { 2 - 4 } $\begin{array}{l}\text { Panel A: Campaign experiment } \\
\text { (no. observations: 444) }\end{array}$ & 1995 & 2001 & $\begin{array}{c}2001-1995 \\
\text { difference }\end{array}$ \\
\hline Access to newspapers & $24.5^{* * *}$ & $83.7^{* * *}$ & $59.2^{* * *}$ \\
& $(2.87)$ & $(1.94)$ & $(3.46)$ \\
No access to newspapers & $29.6^{* * *}$ & $75.0^{* * *}$ & $45.4^{* * *}$ \\
& $(5.40)$ & $(3.11)$ & $(6.22)$ \\
Access-no access difference & -5.12 & $8.68^{* *}$ & $13.8^{* *}$ \\
& $(6.10)$ & $(3.66)$ & $(7.13)$ \\
\hline Panel B: Control experiment & 1991 & 1995 & $1991-1995$ \\
(no. observations: 417) & & & difference \\
\hline Access to newspapers & $3.30^{* *}$ & $24.5^{* * *}$ & $21.2^{* * *}$ \\
& $(1.30)$ & $(2.87)$ & $(3.14)$ \\
No access to newspapers & 2.94 & $29.6^{* * *}$ & $26.7^{* * *}$ \\
& $(1.93)$ & $(5.40)$ & $(5.73)$ \\
Access-no access difference & 0.36 & -5.12 & -5.48 \\
& $(2.32)$ & $(6.10)$ & $(6.61)$ \\
\hline \hline
\end{tabular}

a. Average funding received (in percent), with robust standard errors in parenthesis.

b. $* * *[* *](*)$ denote statistically significant at $1[5]$ (10) percent levels, respectively. 
Table 5. Conditional difference-in-differences estimates of the effects of having a newspaper

\begin{tabular}{lcc}
\hline \hline Specification & $(1)$ & $(2)$ \\
\hline 1995 & $29.6^{* * *}$ & $49.2^{* * *}$ \\
& $(5.4)$ & $(7.3)$ \\
2001 & $75.0^{* * *}$ & $100.7^{* * *}$ \\
& $(3.1)$ & $(7.5)$ \\
Newspaper & -5.12 & -2.18 \\
& $(6.1)$ & $(6.3)$ \\
Newspaper*2001 & $13.8^{* * *}$ & $14.0^{* *}$ \\
& $(7.1)$ & $(7.1)$ \\
\hline Income as control & no & yes \\
$\mathrm{R}^{2}$ & 0.80 & 0.81 \\
Schools & 218 & 218 \\
Observations & 417 & 417 \\
\hline \hline a. Dependent variable is grants received as share of entitled grants. \\
b. Robust standard errors in parenthesis. \\
c. ${ }^{* * *}[* *](*)$ denote statistically significant at $1[5](10)$ percent \\
levels, respectively.
\end{tabular}


Table 6. Head teacher test

\begin{tabular}{|c|c|c|c|c|c|c|}
\hline Specification & (1) & (2) & (3) & (4) & (5) & (6) \\
\hline Dep. var. & $\begin{array}{c}\text { Knowledge } \\
\text { about grant } \\
\text { formula }\end{array}$ & $\begin{array}{c}\text { Knowledge } \\
\text { about } \\
\text { timing } \\
\end{array}$ & Info & $\begin{array}{c}\text { Knowledge } \\
\text { about news } \\
\text { events }\end{array}$ & $\begin{array}{c}\text { Knowledge } \\
\text { about local } \\
\text { affairs }\end{array}$ & $\begin{array}{r}\text { General } \\
\text { political } \\
\text { knowledge }\end{array}$ \\
\hline \multicolumn{7}{|l|}{ Panel $A$} \\
\hline Newspaper & $\begin{array}{l}0.112^{* *} \\
(.056)\end{array}$ & $\begin{array}{l}0.091^{* *} \\
(.046)\end{array}$ & $\begin{array}{c}0.203^{* * *} \\
(.073)\end{array}$ & $\begin{array}{c}0.093^{* * *} \\
(.025)\end{array}$ & $\begin{array}{l}-0.002 \\
(.012)\end{array}$ & $\begin{array}{l}0.027 \\
(.026)\end{array}$ \\
\hline \multicolumn{7}{|l|}{ Panel B } \\
\hline $\begin{array}{l}\text { Distance to nearest } \\
\text { newspaper outlet }\end{array}$ & $\begin{array}{c}-0.063^{* * *} \\
(.021)\end{array}$ & $\begin{array}{l}-0.040^{* *} \\
(.020)\end{array}$ & $\begin{array}{c}-0.103^{* * *} \\
(.029)\end{array}$ & $\begin{array}{c}-0.039^{* * *} \\
(.010)\end{array}$ & $\begin{array}{l}-0.001 \\
(.004)\end{array}$ & $\begin{array}{l}-0.013 \\
(.010)\end{array}$ \\
\hline Range of scores & {$[0,1]$} & {$[0,1]$} & {$[0,1,2]$} & {$[0,1]$} & {$[0,1]$} & {$[0,1]$} \\
\hline Average test & 0.65 & 0.24 & 0.89 & 0.65 & 0.75 & 0.57 \\
\hline Schools & 388 & 388 & 388 & 388 & 388 & 388 \\
\hline
\end{tabular}

a. The dependent variables are in: (1) a binary 1,0 variable indicating correct $(=1)$ [incorrect $(=0)$ ] knowledge about grant formula, (2) a binary variable 1,0 indicating correct $(=1)$ [incorrect $(=0)$ ] knowledge about timing of releases of the grant, (3) the sum [0,2] of "Knowledge about grant formula" and "Knowledge about timing", (4) average score [0,1] on five questions on recent news events, where a correct [incorrect] answer to each question is coded as 1 [0], (5) average score [0,1] on five questions on local affairs, where a correct [incorrect] answer to each question is coded as $1[0],(6)$ average score $[0,1]$ on six questions on general political knowledge, where a correct [incorrect] answer to each question is coded as 1 [0]. See text for details.

b. Average test is average test score.

c. Robust standard errors in parenthesis.

d. $\quad * * *[* *](*)$ denote statistically significant at $1[5](10)$ percent levels. 
Table 7. Newspapers, information, and distance to nearest newspaper outlet

\begin{tabular}{|c|c|c|c|c|c|c|}
\hline Specification & (1) & (2) & (3) & (4) & $(5)$ & (6) \\
\hline Dep. var. & \multicolumn{2}{|c|}{ newspaper } & info & info & info & info \\
\hline $\begin{array}{l}\text { Distance to nearest } \\
\text { newspaper outlet }\end{array}$ & $\begin{array}{c}-0.100^{* * *} \\
(.018)\end{array}$ & $\begin{array}{c}-0.098^{* * *} \\
(.020)\end{array}$ & $\begin{array}{c}-0.103^{* * *} \\
(.029)\end{array}$ & $\begin{array}{c}-0.111^{* * *} \\
(.032)\end{array}$ & $\begin{array}{c}-0.080^{* *} \\
(.038)\end{array}$ & $\begin{array}{c}-0.096^{* * *} \\
(.033)\end{array}$ \\
\hline $\begin{array}{l}\text { Distance to district } \\
\text { headquarters }\end{array}$ & & & & & $\begin{array}{l}-0.065 \\
(.060)\end{array}$ & \\
\hline $\begin{array}{l}\text { Distance to nearest } \\
\text { bank branch }\end{array}$ & & & & & $\begin{array}{l}0.021 \\
(.060)\end{array}$ & \\
\hline Newspaper & & & & & & $\begin{array}{l}0.148^{* *} \\
(.075)\end{array}$ \\
\hline Income as control & no & yes & no & yes & yes & yes \\
\hline Schools & 388 & 388 & 388 & 388 & 388 & 388 \\
\hline
\end{tabular}

a. Robust standard errors in parenthesis.

b. The controls are "income", "share of qualified staff", "school size".

c. ${ }^{* *}\left[{ }^{* *}\right](*)$ denote statistically significant at 1 [5] (10) percent levels. 
Table 8. Reduced form effects

\begin{tabular}{|c|c|c|}
\hline Specification & (1) & $(2)$ \\
\hline \multicolumn{3}{|c|}{ Panel A: Campaign experiment (1995-2001) } \\
\hline 2001 & $\begin{array}{l}66.4^{* * *} \\
(5.31)\end{array}$ & $\begin{array}{l}75.7^{* * *} \\
(7.74)\end{array}$ \\
\hline $\begin{array}{l}\text { Distance to nearest } \\
\text { newspaper outlet }\end{array}$ & $\begin{array}{l}-5.36^{* *} \\
(2.32)\end{array}$ & $\begin{array}{l}-6.77^{* *} \\
(2.62)\end{array}$ \\
\hline Income as control & no & yes \\
\hline Adj. R2 & 0.04 & 0.06 \\
\hline Schools & 199 & 199 \\
\hline \multicolumn{3}{|c|}{ Panel B: Control experiment (1991-1995) } \\
\hline 1995 & $\begin{array}{c}23.7^{* * *} \\
(5.4)\end{array}$ & $\begin{array}{l}18.6^{* *} \\
(7.70)\end{array}$ \\
\hline $\begin{array}{l}\text { Distance to nearest } \\
\text { newspaper outlet }\end{array}$ & $\begin{array}{c}0.64 \\
(2.24)\end{array}$ & $\begin{array}{c}0.62 \\
(2.55)\end{array}$ \\
\hline Income as control & no & yes \\
\hline Adj. R2 & 0.01 & 0.01 \\
\hline Schools & 147 & 147 \\
\hline
\end{tabular}


Table 9. Linking distance, information, and capture

\begin{tabular}{|c|c|c|c|c|}
\hline Specification & (1) & (2) & (3) & (4) \\
\hline $\begin{array}{l}\text { Regression } \\
\text { Dep. variable }\end{array}$ & $\begin{array}{c}2^{\text {nd }} \text { stage } \\
\Delta \mathrm{s}_{\mathrm{jk}}\end{array}$ & $\begin{array}{c}1^{\text {st }} \text { stage } \\
\text { info }_{j k}\end{array}$ & $\begin{array}{c}2^{\text {nd }} \text { stage } \\
\Delta \mathrm{s}_{\mathrm{jk}}\end{array}$ & $\begin{array}{c}2^{\text {nd }} \text { stage } \\
\Delta \mathrm{s}_{\mathrm{jk}}\end{array}$ \\
\hline 2001 & $\begin{array}{c}2.30 \\
(21.1)\end{array}$ & & $\begin{array}{c}0.03 \\
(15.7)\end{array}$ & $\begin{array}{l}-22.9 \\
(22.6)\end{array}$ \\
\hline Info & $\begin{array}{l}65.9^{* * *} \\
(23.5) \\
{[23.6]}\end{array}$ & & $\begin{array}{c}71.6^{* * *} \\
(18.0) \\
{[18.3]}\end{array}$ & $\begin{array}{l}42.8^{*} \\
(24.6) \\
{[25.6]}\end{array}$ \\
\hline Avinfo & & & & $\begin{array}{l}54.5^{* * *} \\
(19.7) \\
{[21.9]}\end{array}$ \\
\hline $\begin{array}{l}\text { Distance to nearest } \\
\text { newspaper outlet }\end{array}$ & & $\begin{array}{c}-0.060^{* *} \\
(.034)\end{array}$ & & \\
\hline $\begin{array}{l}\text { Distance to nearest } \\
\text { newspaper outlet (average) }\end{array}$ & & $\begin{array}{c}-0.308^{* * *} \\
(.070) \\
\end{array}$ & & \\
\hline Controls & yes & yes & yes & yes \\
\hline F-test of instruments & $\begin{array}{c}11.8 \\
\{.000\}\end{array}$ & & $\begin{array}{c}15.9 \\
\{.000\}\end{array}$ & $\begin{array}{r}11.8,28.5 \\
\{.00\},\{.00\}\end{array}$ \\
\hline Hansen J-statistic & & & $\begin{array}{c}0.004 \\
\{0.947\}\end{array}$ & \\
\hline Schools & 199 & 388 & 199 & 197 \\
\hline
\end{tabular}

a. Income is included as control.

b. OLS standard errors in parenthesis and bootstrapped standard errors in square brackets.

c. First-stage regressions for specification (1) is reported in Table 7, column (3).

d. F-test of instruments is the test statistic on the F-test of the joint significance of the instruments in the first-stage regression, with p-values in curly brackets.

e. Hansen J-statistic is the test statistic on the overidentification test of the instruments, with p-values in curly brackets.

f. $* * *[* *](*)$ denote statistically significant at $1[5](10)$ percent levels, respectively. 